\title{
THE USE OF MINI DAIRY IN TEACHING WRITING
}

\author{
Nining Kurniah dan Jajat Imanudin \\ Universitas Islam Al-Ihya Kuningan Jawa Barat, Indonesia \\ Email: niningkurniah05@gmail.com dan imanudinjajat@gmail.com
}

\begin{abstract}
This research is to find out that mini diary as media can generate the students' ability in teaching writing. This research will be based on quantitative and qualitative study. To find out whether mini diary is effective or not in teaching writing recount text of eighth grade students of SMPN 4 Kuningan, the writers analyzed the data using $t$ - test formula. The means score of pre-test of the experimental group is 66,56 and the post-test is 77.09. While the score of pre-test of the control group is 67 and the post-test is 72,5. The result shows that there is significant difference of mean score of the post test in both of the class. In the end of teaching writing recount text, the students' achievement rises as 10,53 while in control class only rise as 5,5. After calculating the data, writers gets that $t$ observation (to) $=2,56$ and with degree of freedom $(d f)$ as 74 and significant level $5 \%$, $t$-table $(t t)=1.67$. In this research, mini diary as media can increase the students' enthusiasm to learn writing. It is shown by the students who pay attention while they are writing their experiences in mini diary. They are also active ask to the teacher when they did not understand or not know how to write correct sentences. Therefore, using mini diary as media makes class atmosphere more fun and comfortable.
\end{abstract}

Keywords: mini diary; teaching; writing

\section{Introduction}

According to Regulation of Culture and Education Ministry (Kemendikbud, 2016) in Contents Standard of primary and secondary education, the ultimate goal of learning English is make students are able to participate in any utterance or to communicate in oral and written English accurately, fluently and in acceptable manner. It implies English should be learnt by students in primary, junior and senior high school.

In syllabus of English subject for Junior High School, students are expected to be able write at least five genres; narrative, recount, descriptive, report and procedure in daily life context. It means, writing is one of language skills that students should accept it. In this study the writers focus in teaching writing one of the five genres, namely is recount text. (Al-Jawi, 2010) points out that writing is one of a way in communicating used by people. It means that English teachers must teach writing to the students in order to communicate with the others well by mastering the writing skill.

(Cook, 2008) says that the basic problem with English for many students, however, is correspondence rules that govern how letters are arranged in words, in other hands is spelling. It implies, the best course of action is to check whether the students know how 
to write the word or not. Most of them often write misspell words. They write words as what they memorize whereas they are different with the correct spelling. Teachers should facilitate a media that will encourage students to study writing English, in order to they can memorize and recognize the correct words to build their writing. (Sari, Refnaldi, \& Rosa, 2013) mention that Writing has a role in language and it takes language out of the restriction and need of time and arrange it systematically.

According to (Vacilotto, S., \& Cummings, 2007) An informed teacher has an extensive knowledge base about teaching. Also a teacher demands to creative in creating media and method which is using in teaching learning method. It means, teaching writing in class must be able to carry out by teacher with the media which is able to increase students interest in writing English.

(Aprilia, 2015) stated that writing can be defined as talking about the ideas, develop them into sentences, and make a good construction of those sentences. By writing a diary, it will be helpful to create the students' enthusiasm and interest in learning English especially in writing. (Ningrum, 2013) says that diary writing has an interesting activities to do and can be used to a kind of writing experiences

According to (Fitzpatrick, 2005), a diary is a record (originally in handwritten format) with discrete entries arranged by date reporting on what has happened over the course of a day or other period. A personal diary may include a person's experiences, and or thoughts or feelings, including comment on current events outside the writers' direct experience.

(Taqi, Akbar, Al-Nouh, \& Dashti, 2015), diary itself can be mentioned as everyday life that notes the events that happen on the day. It is updated on a personal's life. On the other hand, one of the tasks is to practice writing at home by keeping journals or diaries (Tuan, 2010). The points, that writing a journal or a diary is keeping a record of ideas, opinions or descriptions of daily event. One of previous research conducted by (Mutsliah, 2016) the result showed that writing a diary was an effective strategy in process of teaching and learning writing because it could assist students to explore their ideas and improve students' writing skill better. (Barjesteh, Vaseghi, \& Gholami, 2011) in their research found that by a diary writing can be creative and productive in classroom writing activitiy. By writing a diary, it can train and boost students to improve their writing skill.

According to (Fitzpatrick, 2005), a diary is a record (originally in handwritten format) with discrete entries arranged by date reporting on what has happened over the course of a day or other period. A personal diary may include a person's experiences, and or thoughts or feelings, including comment on current events outside the writers's direct experience.

Based on the background above, the writers is interested in doing this research to determine effectiveness of teaching writing by using mini diary as media. In the end analysis, the writers assume that by using mini diary as media can generate the students ability in teaching writing. 


\section{Research Methodology}

This research was carried out at SMP Negeri 4 Kuningan that is located on Jl. R.E. Martadinata No. 76 Cijoho Kuningan. (Fraenkel,J.R \& Wallen, 2009) clarify that research methodology is overall plan for collecting data to answer the research question and explain specifically data analysis and method that intended to use. Employing quasi experimental design, there will be two groups involved in this research, as experimental and control group. The groups will not be informed in advance that they are involved as sample in this research in order to prove the effectiveness of work groups. The control group will run with conventional routine situation in the classroom, while the experimental group will be threated as a treatment class, namely applying mini diary as media in teaching writing recount text. According to the goals of the research, it aims to find out whether using mini diary media is effective or not in teaching writing recount text, therefore, pre-test and post-test are tested to experimental and control class.

Population is a group of element or cases, whether individuals, objects or events can be used as objects and sources in taking data in a research. (Sugiyono, 2011) says that population is a group that has a quality and characteristics to be learnt by the reseearcher in a particular study. Referring to the statements above, the researcher will take students of the eighth grade of SMPN 4 Kuningan as population. The amount is 299 students, consists of 155 boys and 144 girls. Sample is a part that represent the population taken in the study (Arikunto, 2010). In selecting sample, the writers chose one of types from the non-probability sampling, namely purposive sampling which used members of a particular group are purposefully sought after or no randomization. In this case, the sample is divided into two classes. They are 34 students of VIII A, as experimental class and 36 students of VIII B, as control one. Instruments that used in this study are intended to measure the students' achievement in writing skill especially in writing English recount text. The writers used instruments, namely essay test, questionnaire and documentation.

\section{Result and Discussion}

The data obtained of this research are taken from the test result of writing recount text of eighth grade students of SMPN 4 Kuningan. The test is held twice in both of groups, experimental and control group. In starting of the data collection from experimental group, the writer conducts pre-test in the class. The purpose of the pre-test is to check the students ability in writing recount text before having treatment. In this test, the students are asked to write a recount text into two paragraphs based on their happiest experience. There were 34 students who followed this test. The writer finds the students seem difficult when they wrote sentences in English, especially their vocabulary and knowledge of grammar and structure of recount text. It seemed from their scores in pre-test. Some of them got high scores, it is around 80 to 83, but it does not mean that all of them got the highest score, most of the students (76\%) got lower score than 75 . It indicates 8 students or $24 \%$ of the experimental class got the score more than equal to 75 , with the highest score is 883 , the lowest score is 46 and the mean 
score is 66,56. Based on the data, the writer concludes that the students have not understood yet about recount text especially in writing skill. Thus, treatment activity is important to improve students writing ability. The treatment is calling mini diary to order as media.

After giving treatment by applying mini diary as media in teaching writing recount text, the writer conducts post-test in the experimental group to measure the students ability after getting the treatment. In this test, the students are asked to write a recount text into two paragraphs based on their unforgettable experience. The result of the post test shows that most of students $(71 \%)$ got higher score more than equal to 75 , and the others (29\%) got lower score than 75 , with the highest score is 88 , the lowest score is 62 and the mean score is 77,09. Referring to the difference between pretest and post-test score, it can be stated that the students ability in writing recount text of the eighth grade students of SMPN 4 Kuningan who are taught by using mini diary as media is improved. It can be seen from the data that the mean score of post test is 77.09 while pre-test is 66,56 and the standard deviation (SDx) is 11,30. It implies that there is a significant progress of the students achievement score in writing recount text after using mini diary as teaching media.

By comparing the result of students pre-test and post test score in experimental class, the writer finds that students writing ability increases after getting treatment, using mini diary as media. The students motivation in writing English especially recount text increased because the students got fun and interesting situation in teaching writing recount text, so that the students can express their ideas, thought, and feelings to be poured down into recount text in mini diary freely.

Similar to the experimental group, in the first meeting of control group, the students also given pre-test to measure their ability in writing recount text before getting the material. The results are the highest score is 80 , the lowest score is 55 and the mean score is 67. After doing pre-test, the writer gave students material of recount text without using treatment. For the control class, the writer uses common method in teaching. It only explained about past tense, generic structure of recount text to the students without using mini diary as media. After teaching writing recount text in the control group finished, the students also are given post-test which the scores will be compared with the score of the pre-test. In the result of post-test, the writer finds that some of the students got higher score, around 80 to 85 , but it is does not mean that all of them got the high score, most of the students (65\%) still get lower score, namely less than 75 . It means only several students $(24 \%)$ of the control class get the score more than equal to 75 , the highest score is 85 while the lowest score is 61 and the mean score is 72.5. The result of post-test in the control class shows that the students writing ability is better than before but most of them still got lower scores or less than 75 .

Referring to post-test scores in the control class above, then it is compared with pre-test scores, there is increase of students' writing ability. Based on the result of the whole test in control class, it can be seen that the mean score of post test is 72.5 , pre-test 
is 67 and the standard deviation (SDy) is 0,97. It means, there is improvement of the students' ability in writing recount text but not quite significant.

To find out whether mini diary is effective or not in teaching writing recount text of eighth grade students of SMPN 4 Kuningan, the writer analyzes the data using t- test formula. The means score of pre-test of the experimental group is 66,56 and the posttest is 77.09. While the score of pre- test of the control group is 67 and the post- test is 72,5. The result shows that there is significant difference of mean score of the post test in both of the class. In the end of teaching writing recount text, the students' achievement rises as 10,53 while in control class only rise as 5,5. After calculating the data, writer gets that t-observation (to) $=2,56$ and with degree of freedom (df) as 74 and significant level $5 \%$, $\mathrm{t}$-table $(\mathrm{tt})=1.67$.

Since t-observation is higher than $\mathrm{t}$ table $(\mathrm{to}=2,56>\mathrm{t}$ - table $=1.67)$, the alternative hypothesis is accepted and the null hypothesis (Ho) is rejected. Thus, it can be concluded that there is a significant difference of achievement in teaching writing recount text of the students who are taught by using mini diary as media at the eighth grade SMPN 4 Kuningan than the students who are not.

The writer finds that teaching writing recount text by using mini diary as media is effective to the students. It is shown not only from the result of their scores but also their attraction to study by using a media they had never used before. Based on the percentages of questionnaires that the writer has calculated, $82 \%$ of students or almost all of the students like learning English, but when they have to write recount text, they have less of enthusiastic. It shows from their attention which always distract each others. They do not like to write in English. Based on the questionnaire, the writer finds that, $65 \%$ of the students or half of the students got difficulties in writing English as how to get an idea, what they should write, how to arrange the words into sentence in English and so forth.

After getting treatment, 94\% of students or almost all of the students stated that they got new experience when using mini diary as media in teaching writing recount text. From their responses, it shows that the students like learning English, but they found difficulties in writing English when they given a media in teaching writing English they felt getting a new experience. It means media is important to attract students' attention to study English.

The use of mini diary as media in teaching writing recount text, can increase the students' motivation in teaching writing especially in recount text. It goes a long with the students' responses. $71 \%$ of students or half of the students believe that mini diary as media can increase their motivation in writing English. $91 \%$ or almost all of the students opine, it facilitates them to comprehend recount text more and enlarge their vocabularies. It is caused by using mini diary as media in writing English especially recount text, the students can pour their idea, thought or feeling freely without being afraid of grammatical error by using mini diary. The writer also does not blame the students when they make mistakes in grammatically, the other students neither agree nor disagree of the statement. 
While doing the treatment, $76 \%$ or almost all of the students agree that mini diary is as an interesting media in teaching writing English. They also state that it is very impression of applying mini diary as media in teaching recount text, since $100 \%$ of students absolutely agree and strongly agree of the statement. And the last $76 \%$ of students or almost all of the students state, it is very fun when using mini diary as media to their learning.

In this research, mini diary as media can increase the students' enthusiasm to learn writing. It is shown by the students who pay attention while they are writing their experiences in mini diary. They are also active ask to the teacher when they did not understand or not know how to write correct sentences. Therefore, using mini diary as media makes class atmosphere more fun and comfortable.

\section{Conclusion}

The conclusion is made based on the findings that have been discussed in the previous chapter. The result of the study indicates that using mini diary in teaching writing especially recount text can give some benefits for students. Mini diary media can increase their motivation in learning writing, facilitate them to comprehend of recount text and enlarge their vocabulary.

Based on the result of the research, the writers recommend several things to the follow-up studies. The suggestion is addressed to English teachers and further researchers who are interested in the same field.

In teaching writing, English teachers are recommended to implement mini diary as media in teaching writing recount text, since it increases the students' motivation to write English especially recount text. Besides, the students feel comfortable enough to pour down their ideas, thought or feeling into written form. Teaching writing by using mini diary as media is better than conventional method that is usually used by English teacher in writing recount text. English teacher is suggested always to give feedback of the students writing so that they will know their mistakes or errors since they commonly made a lot of mistakes in their writing. By giving feedback continuously, sooner or later, the studentsb writing will be better day by day.

There are some suggestions for further researchers who are also interested to investigate the use of mini diary in teaching writing recount text. It would be better to implement mini diary as media in writing process longer and provide a lot of texts in teaching recount text. To make the real response, further researchers should add the research instrument by doing interview. The last, the further researchers are recommended to conduct their studies on the implementation of mini diary not only in recount text but also in other text. 


\section{BIBLIOGRAFI}

Al-Jawi, Fadwa D. (2010). Teaching the receptive skills. Retrieved June, 17, 2017.

Aprilia, Aprilia. (2015). Improving Writing Ability Of The Eighth Grade Students By Using Diary Writing. E-Journal of ELTS (English Language Teaching Society), $3(1)$.

Arikunto, Suharsimi. (2010). Metode Peneltian. Jakarta: Rineka Cipta.

Barjesteh, Hamed, Vaseghi, Reza, \& Gholami, Reza. (2011). The effect of diary writing on EFL college students' writing improvement and attitudes. International Conference on Languages, Literature and Linguistics IPEDR, 26, 143-147.

Cook, S. (2008). The essential guide to employee engagement: better business performance through staff satisfaction. Kogan Page Publishers.

Fitzpatrick, M. (2005). Engaging Writing Paragraph and Essay. London: Longman.

Fraenkel,J.R \& Wallen, N. (2009). How to Design and Evaluate Research in Education. New York: McGraw-hill.

Kemendikbud. (2016). Silabus Mata Pelajaran Sekolah Menengah Pertama/Madrasah Tsanawiah Mata Pelajaran Bahasa Inggris. Jakarta: Kemendikbud.

Mutsliah, Nur Millah. (2016). The Effectiveness of Diary Writing on Students' Writing of Recount Text (A Quasi-experimental Study at the Eighth Grade of SMPN 166 Jakarta in the Academic Year 2015/2016).

Ningrum, Vita. (2013). Improving Writing Skill in Writing Recount Text Through Diary Writing. E-Journal of ELTS (English Language Teaching Society), 1(1).

Sari, Fitri Purnama, Refnaldi, Refnaldi, \& Rosa, Rusdi Noor. (2013). An Analysis Of Students'ability And Problems In Writing Recount Texts At Grade Viii Of Smpn 29 Padang. Journal of English Language Teaching, 2(1), 73-85.

Sugiyono, Prof. (2011). Metodologi penelitian kuantitatif kualitatif dan R\&D. Alpabeta, Bandung.

Taqi, Hanan A., Akbar, R. S., Al-Nouh, N. A., \& Dashti, A. A. (2015). The Effect of Diary Writing on EFL Students' Writing and Language Abilities. British Journal of Education, 3(2), 75-91.

Tuan, Luu Trong. (2010). Enhancing EFL Learners' Writing Skill via Journal Writing. English Language Teaching, 3(3), 81-88.

Vacilotto, S., \& Cummings, R. (2007). Peer coaching in TEFL/TESL programmes. ELT Journal, 61(2), 153-160. 